\title{
Effect of Insulin-like Growth Factor-1 on the Responses to and Recognition of Hypoglycemia in Humans
}

\section{A Comparison with Insulin}

David Kerr, William V. Tamborlane, Frances Rife, and Robert S. Sherwin

Departments of Internal Medicine, Pediatrics, and the General Clinical Research Center,

Yale University School of Medicine, New Haven, Connecticut 06510

\begin{abstract}
Recombinant human insulin-like growth factor-1 (rhIGF-1) lowers blood glucose in humans but its effect on counterregulatory responses has not been established. We therefore compared infusions of rhIGF-1 $(0.7 \mu \mathrm{g} / \mathrm{kg}$ per $\mathrm{min})$ and insulin $(0.8 \mathrm{mU} / \mathrm{kg} \cdot \mathrm{min})$ for $120 \mathrm{~min}$ in 10 healthy volunteers (glucose allowed to fall freely). With both, glucose fell rapidly because of stimulation of glucose uptake and suppression of hepatic glucose production. Despite similar plasma glucose nadirs $(2.6 \pm 0.1$ vs. $2.7 \pm 0.1 \mathrm{mM})$, the glucagon response was absent $(P<0.005)$, growth hormone release was attenuated $(P$ $<0.03)$, and norepinephrine levels were increased $(P<0.05)$ by rhIGF-1 compared with insulin. Absent glucagon responses were associated with a blunting of the rebound increase in glucose production ( $P<0.05$ vs. insulin ). After stopping the infusions, glucose recovery was delayed with $\mathrm{rhIGF-1}(P<0.001$ vs. insulin ). To further evaluate the effects of rhIGF-1 during a standard hypoglycemic stimulus, eight additional healthy subjects received rhIGF-1 or insulin while glucose was clamped at $2.8 \mathrm{mM}$. Again the rise in glucagon during insulin-induced hypoglycemia was totally abolished by rhIGF-1. Growth hormone responses were delayed, whereas increases in norepinephrine, heart rate, and symptomatic awareness of hypoglycemia were greater with rhIGF-1 compared with insulin $(P<0.05)$. It was concluded that rhIGF-1 suppression of glucagon release during hypoglycemia impairs glucose recovery. Paradoxically, awareness of hypoglycemia is enhanced with rhIGF-1 in part due to stimulation of the sympathetic activity. (J. Clin. Invest. 1993. 91:141-147.) Key words: insulin • insulin-like growth factor-1 • hypoglycemia $\cdot$ glucose counterregulation
\end{abstract}

\section{Introduction}

Insulin-like growth factor-1 (IGF-1), ${ }^{1}$ the putative mediator of the somatotrophic action of growth hormone has rapid insulinlike effects on protein metabolism and slower actions on cell proliferation and differentiation (1). Recombinant human

Address reprint requests to Dr. David Kerr, Royal Bournemouth Hospital, Castle Lane East, Bournemouth, BH7 7DW, United Kingdom.

Received for publication 8 May 1992 and in revised form 24 July 1992.

1. Abbreviations used in this paper: ANOVA, analysis of variance; IGF1, insulin-like growth factor-1; rhIGF-1, recombinant human IGF-1.

J. Clin. Invest.

(C) The American Society for Clinical Investigation, Inc.

$0021-9738 / 93 / 01 / 0144 / 07 \quad \$ 2.00$

Volume 91, January 1993, 141-147
IGF-1 (rhIGF-1) has been used successfully to improve protein balance in patients with growth hormone resistance (2) and hypercatabolic states (3), suggesting that rhIGF-1 may also be a useful treatment for conditions associated with insulin resistance, such as diabetes mellitus (4). However, use of rhIGF-1 to stimulate growth and protein anabolism may be limited by its glucose-lowering effects.

The effects of rhIGF-1 on glucose metabolism vary between species and between disease states. In nondiabetic rats, rhIGF1 stimulates peripheral glucose uptake but, unlike insulin, is relatively ineffective in suppressing hepatic glucose production $(5,6)$. In spontaneously diabetic $\mathrm{BB} / \mathrm{w}$ rats, infusion of rhIGF- 1 is able to suppress elevated rates of glucose production as well as to stimulate glucose uptake (7), the suppressive effect of rhIGF-1 on hepatic glucose production being greater than that observed with insulin. In contrast to the findings in nondiabetic animals, rhIGF-1 has been shown to markedly inhibit hepatic glucose production in humans, even at doses that only modestly stimulate peripheral glucose uptake (8). In that study, however, the glucose clamp technique was used to maintain euglycemia.

Bolus injections of rhIGF-1 can cause hypoglycemia in healthy human volunteers (9), but the kinetic mechanisms underlying hypoglycemic counterregulation during rhIGF-1 infusion in humans have not been determined. Even less is known about the comparative effects of rhIGF-1 and insulin on the hormonal, symptomatic, and physiological responses to hypoglycemia. The aim of this study was to evaluate whether the response to rhIGF-1-induced hypoglycemia is distinguishable from that produced by insulin. Two different methods of inducing hypoglycemia were used. In the first, the effects of the peptides on glucose counterregulation were examined directly by allowing plasma glucose levels to fall freely during 2 -h infusions of rhIGF-1 and an equipotent dose of insulin. The doses of rhIGF-1 and insulin were chosen on the basis of preliminary experiments to ensure that they were sufficient to induce and maintain hypoglycemia despite a brisk counterregulatory response. In this experiment, recovery from hypoglycemia was compared after stopping the hormone infusions. In a second protocol, the hormonal, symptomatic, cognitive, and cardiovascular responses to a standardized hypoglycemic stimulus induced by rhIGF-1 or insulin were assessed using the glucose clamp technique (10). This method allows comparisons of these responses while avoiding the confounding effects of variations in the rate and magnitude of the fall in plasma glucose.

\section{Methods}

18 healthy volunteers (age range $18-33 \mathrm{yr}$ ) who were within $120 \%$ of ideal body weight participated in the study, which was approved by the Human Investigations Committee of Yale University. None had any 
history or clinical evidence of medical illness, and none was taking any medications. Informed written consent was obtained from each volunteer. In each of the two experimental protocols described below, paired rhIGF-1 and insulin experiments were performed $\geq 1$ wk apart in a random order. To avoid any potential confounding effects of gender on the hormonal response to induced hypoglycemia (11), a paired study design was used and mainly men were recruited.

All studies were performed in the Yale General Clinical Research Center on the morning of the study after a 10-h overnight fast. Two intravenous catheters were inserted under local anesthesia; one in an antecubital vein for infusion of test substances (see below), and a second, inserted retrograde into a dorsal hand vein, for sampling of arterialized venous blood. The hand was placed in a heated box $\left(65^{\circ} \mathrm{C}\right)$ and the cannula kept patent by a $154 \mathrm{mM} \mathrm{NaCl}$ infusion. In both protocols subjects were told that their blood glucose would be lowered at some stage but they were not told the level at any time.

Free-fall hypoglycemia protocol. 10 subjects ( 8 male) were studied on two separate occasions. A primed-continuous infusion of $3-\left[{ }^{3} \mathrm{H}\right]$ glucose $\left(25 \mu \mathrm{Ci}\right.$ bolus, $0.25 \mu \mathrm{Ci} \mathrm{min}^{-1}$ ) was given for $120 \mathrm{~min}$, after insertion of the cannulae, to allow equilibration of the tracer. After the tracer equilibration period, subjects received, in a random order, either a primed-continuous infusion of human regular insulin $(0.8$ $\left.\mathrm{mU} \cdot \mathrm{kg}^{-1} \cdot \mathrm{min}^{-1}\right)$ (Eli Lilly and Company, Indianapolis, IN) or IGF$1\left(0.7 \mu \mathrm{g} \cdot \mathrm{kg}^{-1} \cdot \mathrm{min}^{-1}\right)($ Genentech Inc., San Francisco, CA $)$ for 120 min. The priming dose was given over the initial $10 \mathrm{~min}$ at twice the continuous infusion rate. Plasma glucose was allowed to fall and levels were determined every $5 \mathrm{~min}$ in duplicate at the bedside by a glucose oxidase method (Beckman Instruments, Inc., Fullerton, CA). After $120 \mathrm{~min}$, the insulin or rhIGF-1 infusions were stopped and plasma glucose was allowed to "recover" over a further $100 \mathrm{~min}$.

Arterialized venous blood samples were taken for subsequent measurement of insulin, C-peptide, IGF-1, and counterregulatory hormone levels every 10-40 min. Samples for kinetic determinations were taken at $10 \mathrm{~min}$ intervals over the final $30 \mathrm{~min}$ of the equilibration period and at 10- to 15-min intervals throughout the study.

Hypoglycemic clamp protocol. Eight men participated in two studies performed at least $1 \mathrm{wk}$ apart. At the start of the study (time 0 ), subjects were randomized to receive either a primed-continuous infusion of human insulin $\left(6.5 \mathrm{mU} / \mathrm{kg}\right.$ over $\left.10 \mathrm{~min}, 1.3 \mathrm{mU} \cdot \mathrm{kg}^{-1} \cdot \mathrm{min}^{-1}\right)$ or IGF-1 $\left(40 \mu \mathrm{g} / \mathrm{kg}\right.$ prime, $\left.0.8 \mu \mathrm{g} \cdot \mathrm{kg}^{-1} \cdot \mathrm{min}^{-1}\right)$, which was continued for the duration of the study. An infusion of $20 \%$ glucose solution (Harvard Apparatus, Millis, MA) was used to maintain plasma glucose levels at predetermined values, on the basis of duplicate glucose measurements made every $5 \mathrm{~min}$ as described above. During both visits, plasma glucose levels were "clamped" at $5.0 \mathrm{mM}$ for $120 \mathrm{~min}$ (euglycemic period), thereafter lowered over $30 \mathrm{~min}$ to $2.8 \mathrm{mM}$ and maintained at this level for a further $2 \mathrm{~h}$ (hypoglycemic period). We used slightly higher doses of rhIGF-1 and insulin than in the free-fall study to be able to maintain plasma glucose at $2.8 \mathrm{mM}$ after release of counterregulatory hormones.

Heart rate and blood pressure were recorded every $30 \mathrm{~min}$ by an automated oscillometric method (Accutor 1A monitor; Datascope Corp., Paramus, NJ). At baseline, before starting the infusions, at the end of the euglycemic period, and after 30 and $100 \mathrm{~min}$ of hypoglycemia, evaluations of the symptomatic and cognitive responses to hypoglycemia were made. Subjects completed a questionnaire assessment of symptoms (facial flushing, palpitations, tingling, trembling, sweating, hunger, blurred vision, and sleepiness) and awareness of hypoglycemia using 100-mm visual analogue scales (12). The extremes of the scale were "absent" and "severe."

Cognitive function was determined using P300 auditory evoked responses as previously described (13). Briefly, scalp electrodes were placed at $\mathrm{Cz}$ and $\mathrm{Pz}$ positions with reference and ground electrodes placed on the mastoid processes. $\mathrm{P} 300$-evoked potentials were obtained with an auditory (oddball) categorization task in which subjects silently counted a number of soft clicks delivered in a train of frequent loud and infrequent soft clicks. Duplicate measurements were made at each time point.
Blood was sampled at 20 to 30 -min intervals for measurement of insulin, IGF-1, glucagon, epinephrine, norepinephrine, growth hormone, and cortisol levels.

Analytical methods. Tritiated glucose-specific activity was determined by modification of the Somogyi precipitation procedure as previously described (14). Basal turnover of glucose was calculated by dividing the tracer infusion rate by the mean of three measurements of $\left[{ }^{3} \mathrm{H}\right.$ ]glucose-specific activity obtained during the last $30 \mathrm{~min}$ of the equilibration period. The rate of endogenous glucose production and total body glucose uptake were estimated using a two-compartment model of glucose kinetics described elsewhere (15). Plasma IGF-1 levels (total) were measured by double-antibody radioimmunoassay after acid ethanol extraction using a polyclonal rabbit anti-recombinant IGF-1 antibody (Genentech Inc.). The intra- and interassay coefficients of variation for the total IGF-1 assay were 2-7 and 12-19\%, respectively (16). Plasma insulin, C-peptide, glucagon, cortisol, and growth hormone levels were measured using commercially available kits as previously described $(17,18)$ and catecholamines were measured by a radioenzymatic technique (Amersham Corp., Arlington Heights, IL).

Statistics. Statistical analyses were performed using repeated measures analysis of variance (ANOVA) (19). Where ANOVAs were significant, contrasts in means were compared using paired Student's $t$ tests. Where data were not normalized after logarithmic transformation (e.g., hypoglycemic symptoms), comparisons were made using Wilcoxon signed rank and Kruskal-Wallis nonparametric tests. Baseline values represent the mean of two or three preinfusion values taken at 10-r.in intervals. Unless otherwise stated, data are presented as mean \pm SE.

\section{Results}

\section{Free-fall hypoglycemia protocol}

Effect of insulin and IGF-1 infusions on glucose, insulin, C-peptide, and IGF-1 levels. Plasma glucose, insulin, C-peptide, and IGF-1 levels achieved during each study are shown in Fig. 1. Fasting $(4.6 \pm 0.1,4.7 \pm 0.1 \mathrm{mM})$, rate of fall, and nadir $(2.6 \pm 0.1$ and $2.7 \pm 0.1 \mathrm{mM})$ plasma glucose values were similar in each study as were plateau values over the final $60 \mathrm{~min}$ of the infusion periods. However, recovery from hypoglycemia was significantly delayed after infusion of rhIGF-1 $(P<0.001$ vs. insulin), with plasma glucose levels still below fasting values $100 \mathrm{~min}$ after stopping the rhIGF-1 infusion. In the insulin study, plasma insulin levels (400-450 $\mathrm{pM}$ ) reached a plateau within $10 \mathrm{~min}$ and throughout the insulin infusion, falling to basal levels by $40 \mathrm{~min}$ after discontinuation of the insulin infusion. In the rhIGF-1 study, IGF-1 levels (400-450 ng/ml) also reached a stable plateau by $40 \mathrm{~min}$ but in contrast to the insulin study, levels of IGF-1 remained significantly elevated above baseline $(P<0.001)$ after cessation of the hormone infusion. The rate of fall and magnitude of suppression of $C$-peptide were similar in both studies but unlike the rhIGF-1 study, Cpeptide levels increased significantly after stopping the insulin infusion but remained suppressed for $100 \mathrm{~min}$ after discontinuing the rhIGF-1 infusion $(P<0.001$ compared with insulin $)$.

Effect of insulin and IGF-1 on glucose counterregulation. Levels of counterregulatory hormones during the free-fall hypoglycemia study are shown in Fig. 2. The rise in plasma glucagon seen during insulin-induced hypoglycemia was blocked by infusion of rhIGF-1; by 120 min, glucagon levels had risen from $111 \pm 18$ to $158 \pm 25 \mathrm{ng} /$ liter in the insulin study $(P<0.05)$ but were unchanged from baseline ( $109 \pm 17$ vs. $105 \pm 21 \mathrm{ng} /$ liter $)$ with rhIGF-1 $(P<0.005$ vs. insulin $)$. Similarly, the rise in growth hormone was also attenuated by rhIGF-1, increasing from $3.0 \pm 0.7$ to $13.8 \pm 5.4 \mu \mathrm{g} /$ liter after 70 min compared with 

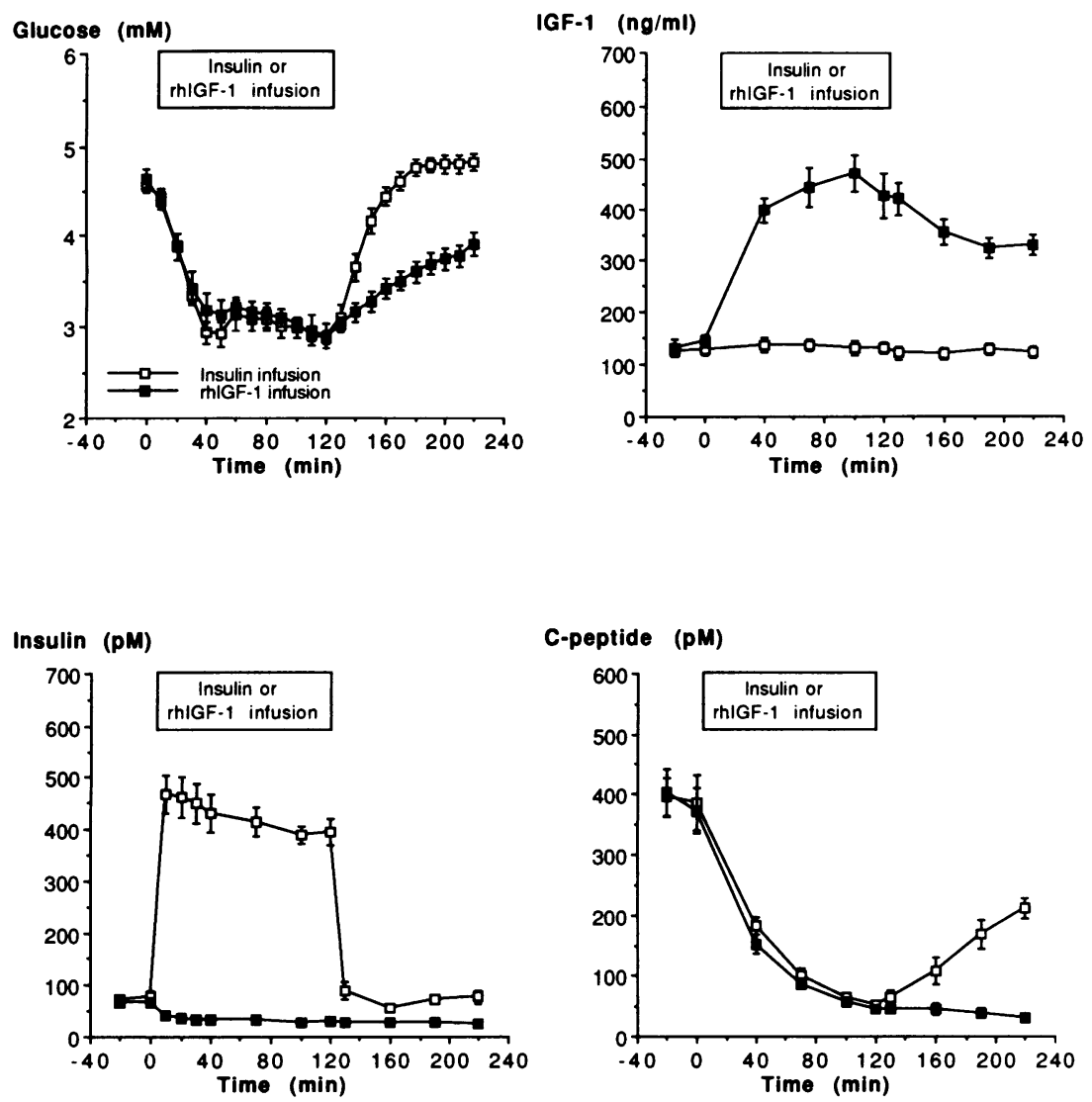

Figure 1. Effect of insulin and rhIGF-1 infusions on levels of glucose, insulin, C-peptide, and IGF-1 during the free-fall hypoglycemia study.

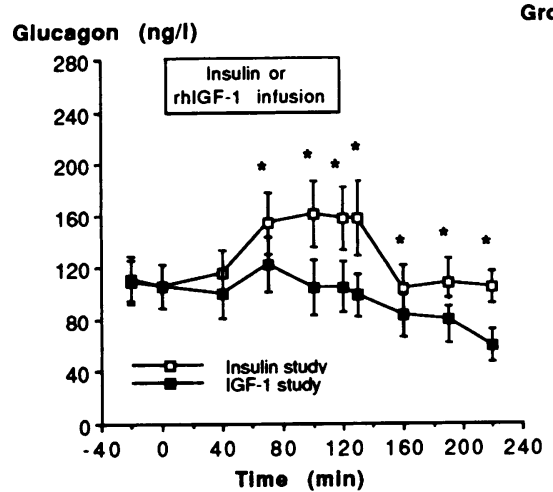

Growth hormone $(\mu \mathrm{g} / \mathrm{l})$
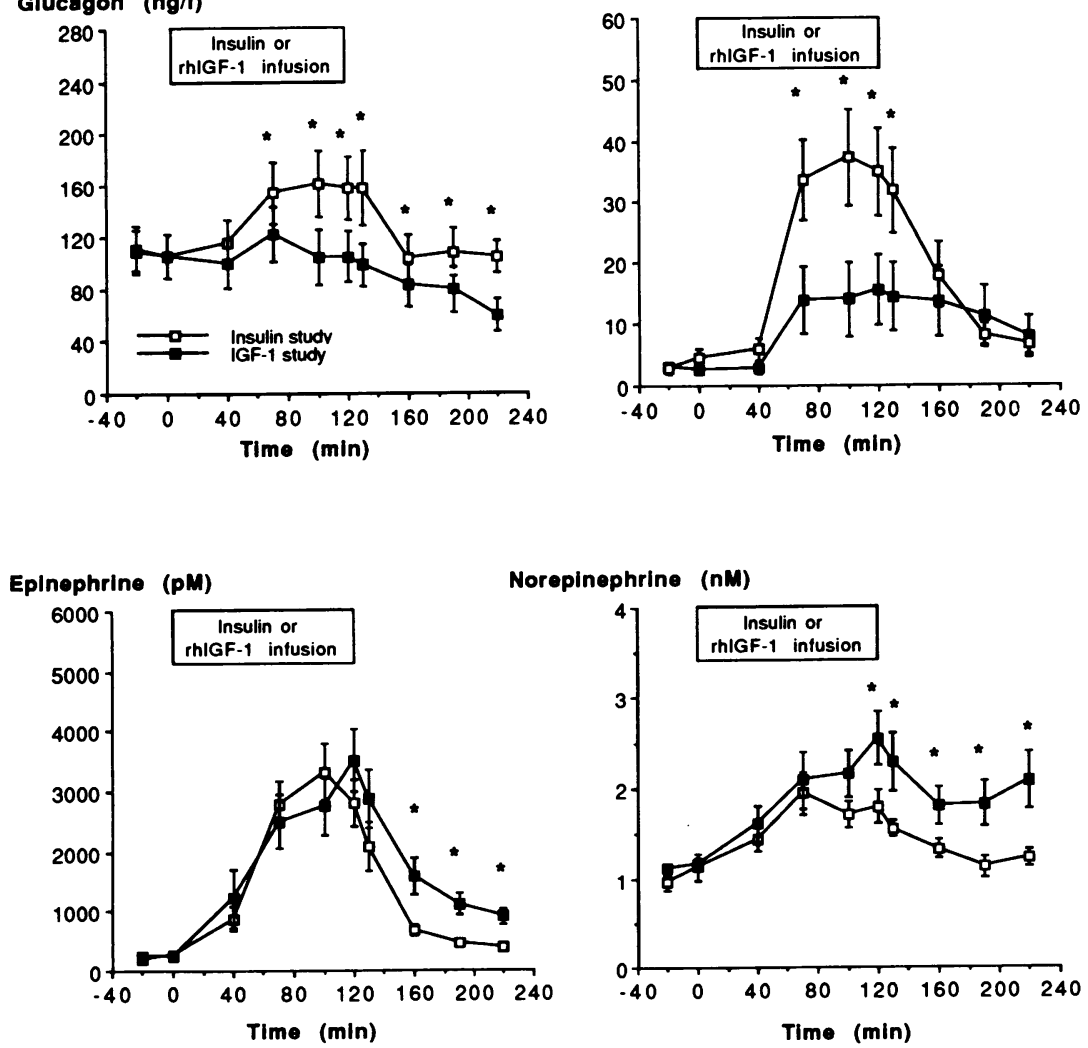

Figure 2. Counterregulatory hormone levels during the free-fall hypoglycemia study. The glucagon response to hypoglycemia was absent $(P<0.005$ by ANOVA $)$, growth hormone levels were lower $(P<0.03)$, and norepinephrine levels were higher $(P<0.05)$ during infusion of rhIGF-1 compared with insulin. Asterisks indicate comparisons of group means at individual time points. ( ${ }^{*} P<0.05$ rhIGF-1 vs. insulin). 


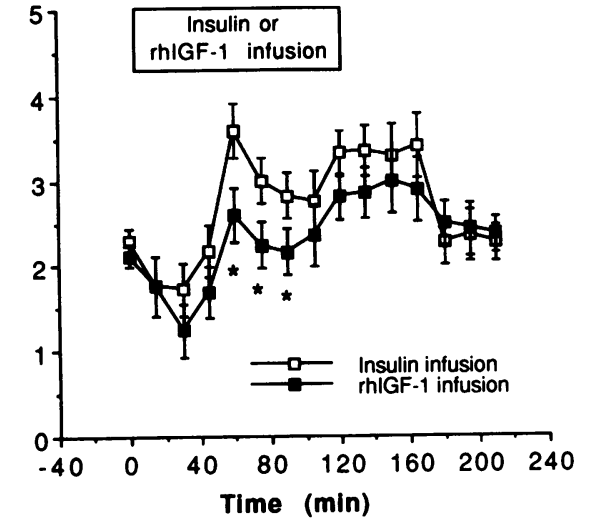

Rd (mg/kg.min)

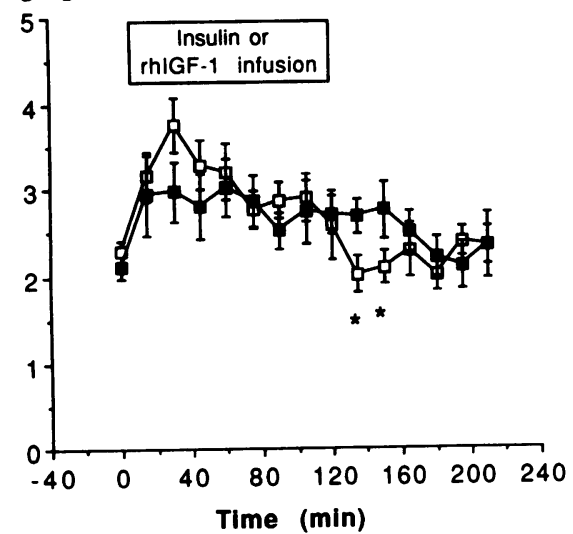

Figure 3. Rates of hepatic glucose production $(R a)$ and total glucose uptake $(R d)$ during the free-fall hypoglycemia study. ${ }^{*} P<0.05$ rhIGF-1 vs. insulin.

a rise from $2.9 \pm 0.9$ to $33.6 \pm 6.6 \mu \mathrm{g} /$ liter during the insulin infusion $(P<0.05)$. Growth hormone levels remained significantly higher during the insulin study until the infusion was discontinued. In contrast, norepinephrine levels were significantly elevated at the end of the rhIGF- 1 infusion $(2.55 \pm 0.30$ vs. $1.78 \pm 0.19 \mathrm{nM}$ for insulin at $120 \mathrm{~min}, P<0.05)$ and remained higher in the rhIGF- 1 study after cessation of the hormone infusions. Epinephrine levels were similar during the hypoglycemic phase of both studies. However, after cessation of the hormone infusions, epinephrine levels returned to baseline more rapidly after insulin than rhIGF-1 (Fig. 2) in association with the more rapid return of plasma glucose to preinfusion values. Cortisol responses (data not shown) were similar between the two studies.

As shown in Fig. 3, hepatic glucose production decreased and peripheral glucose uptake increased within $30 \mathrm{~min}$ from the onset of the hormone infusions in both studies $(P<0.05 \mathrm{vs}$. baseline). During the insulin infusion, hepatic glucose production quickly rebounded to values significantly above baseline ( rising to $3.6 \pm 0.5 \mathrm{mg} \cdot \mathrm{kg}^{-1} \cdot \mathrm{min}^{-1}$ ) whereas hepatic glucose production only rebounded to baseline values $(2.6 \pm 0.3$ $\left.\mathrm{mg} \cdot \mathrm{kg}^{-1} \cdot \mathrm{min}^{-1}\right)$ with rhIGF-1 $(P<0.05$ between studies $)$. On the other hand, the initial increase in glucose uptake $\left(3.7 \pm 0.3\right.$ vs. $3.0 \pm 0.3 \mathrm{mg} \cdot \mathrm{kg}^{-1} \cdot \mathrm{min}^{-1}, P=\mathrm{NS}$ ) was slightly greater during insulin than rhIGF-1 infusion, explaining the similar glucose fall in both studies. Rapid recovery from hypoglycemia after stopping the insulin infusion was accounted for
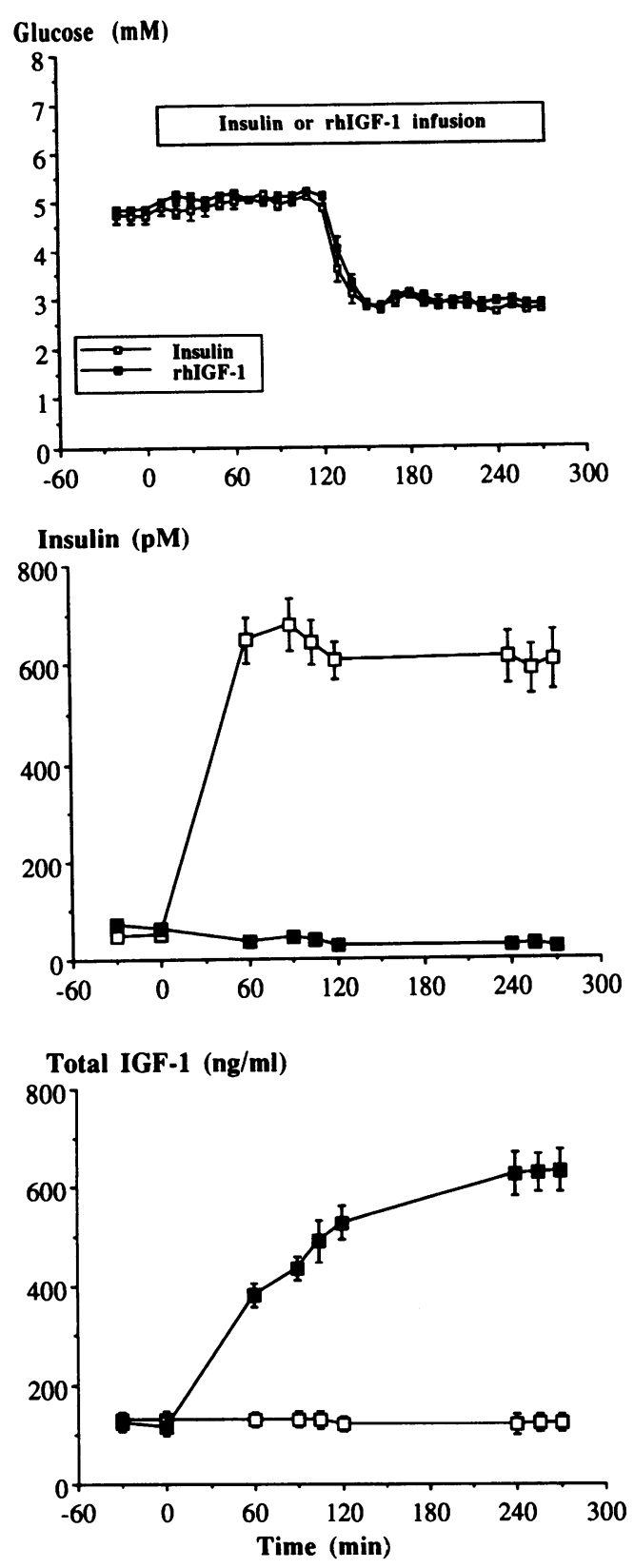

Figure 4. Effect of insulin and rhIGF-1 infusions on levels of glucose, insulin, and IGF-1 during the glucose clamp study.

by a prompt reduction in peripheral glucose uptake and persistant stimulation of glucose production. In the rhIGF-1 study the slower glucose recovery after cessation of the hormone infusion was largely due to the failure of glucose uptake to fall ( $P$ $<0.05$ compared with insulin) (Fig. 3).

\section{Hypoglycemic clamp protocol}

Plasma glucose, insulin, and IGF-1 levels. Plasma glucose, insulin, and total IGF-1 levels achieved during each study are shown in Fig. 4. Infusion of rhIGF-1 suppressed insulin levels below baseline $(P<0.05)$, whereas IGF-1 levels were not affected by insulin infusion. In the final $30 \mathrm{~min}$ of hypoglycemia, levels of IGF-1 were significantly higher than during the corresponding period of euglycemia $(P<0.01)$. Plasma insulin, on the other hand, remained relatively stable throughout the entire study. 

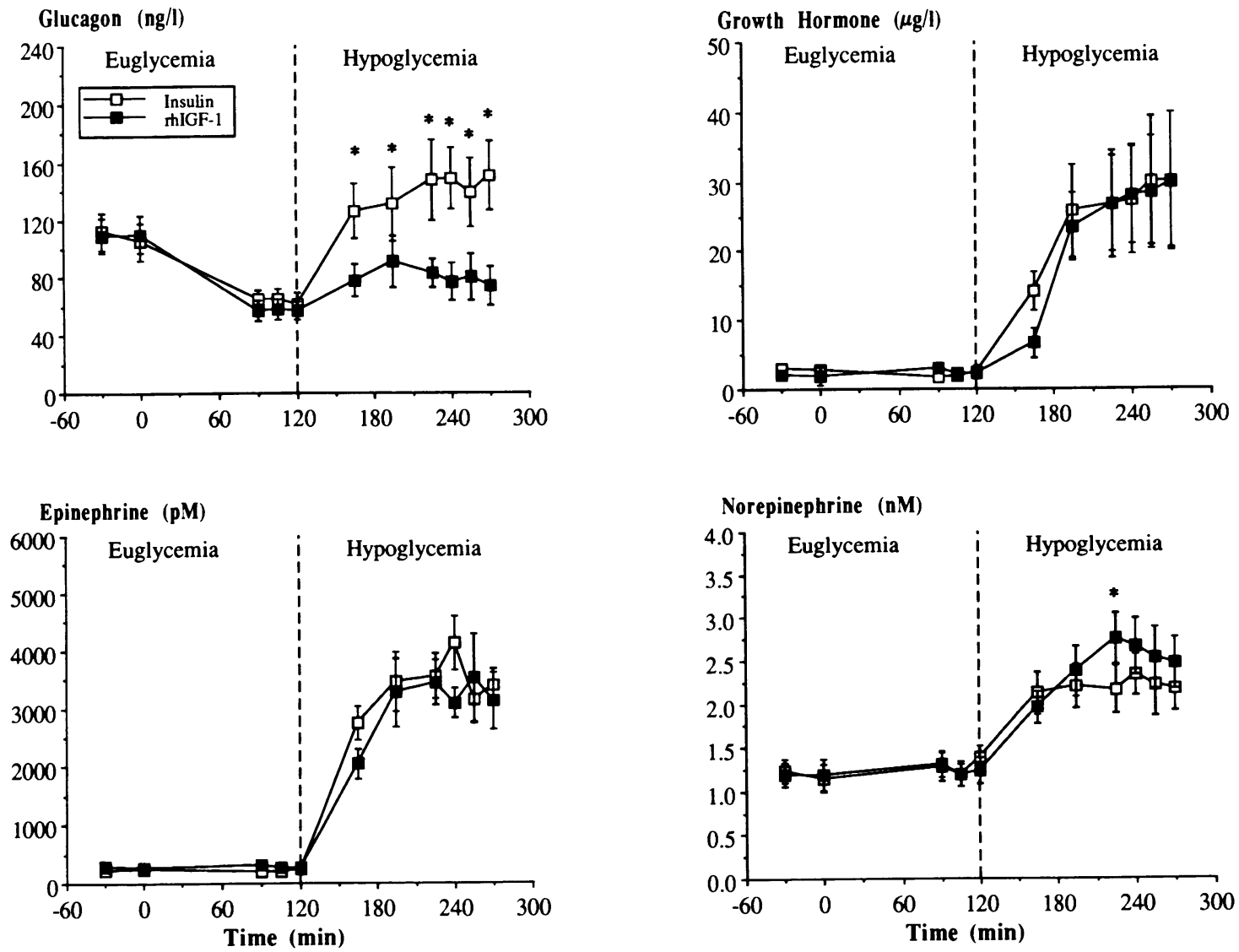

Figure 5. Levels of counterregulatory hormones at baseline, over the final $30 \mathrm{~min}$ of euglycemia, and during hypoglycemia in the clamp study. The glucagon response to hypoglycemia was abolished $(P<0.002$ by ANOVA $)$ and the norepinephrine response was enhanced $(P<0.05)$ by rhIGF-1 compared with insulin. Asterisks indicate comparisons of group means at individual time points $\left({ }^{*} P<0.05\right)$.

Counterregulatory hormone levels. During the euglycemic phase of both studies plasma glucagon was suppressed by $\sim 50 \%$ (Fig. 5). Plasma glucagon rose briskly from nadir values when blood glucose was lowered to $2.8 \mathrm{mM}$ by insulin (from $65 \pm 8$ to $150 \pm 24 \mathrm{ng} /$ liter, $P<0.05$ ). In contrast, rhIGF1 -induced hypoglycemia caused a negligible change in glucagon from nadir values ( from $57 \pm 6$ to $74 \pm 13 \mathrm{ng} /$ liter). Plasma glucagon during the rhIGF-1 study was substantially lower than at corresponding times during the insulin study ( $P$ $<0.002$ ). The growth hormone response to hypoglycemia was delayed in the rhIGF-1 study $(P<0.05)$ for the initial $60 \mathrm{~min}$ after plasma glucose was lowered to $2.8 \mathrm{mM}$ but thereafter responses were similar in both studies. In contrast, the overall plasma norepinephrine response during the hypoglycemic phase of both clamp studies was greater during infusion of rhIGF-1 compared with insulin $(2.7 \pm 0.3$ vs. $2.2 \pm 0.3 \mathrm{nM}, P$ $<0.05$ by ANOVA). Epinephrine and cortisol responses (data not shown) were similar in both studies.

Cardiovascular, cognitive and symptomatic changes. As shown in Table I, systolic blood pressure rose and diastolic blood pressure fell to the same extent in both studies during hypoglycemia. Infusion of rhIGF-1 caused a significant increase in heart rate during the euglycemic phase of the study $(P$ $<0.01$ compared with insulin) that was sustained throughout hypoglycemia $(P<0.05)$. Lowering the blood glucose to 2.8 $\mathrm{mM}$ was associated with a similar increase in latency and decrease in amplitude of the P300 wave in both studies (both $P$ $<0.05$ ). As shown in Fig. 6, symptomatic awareness of hypo- glycemia and hunger were significantly enhanced by rhIGF-1 $(P<0.05$ vs. insulin $)$ as assessed by the visual analogue scales. There was also a tendency for other symptoms to be more intense with rhIGF-1, but these differences did not reach statistical significance.

\section{Discussion}

In this study the effects of rhIGF-1 and insulin on the physiological responses to hypoglycemia and glucose counterregulation were compared using two different experimental techniques. During the free-fall study, rhIGF- 1 abolished the rise in plasma glucagon and attenuated the growth hormone response to a reduction in plasma glucose as compared with insulin. The fall in plasma glucose induced by rhIGF-1 was caused by prompt suppression of hepatic glucose production as well as stimulation of peripheral glucose uptake. These metabolic actions were most likely due to direct effects of rhIGF-1 since endogenous insulin secretion, as assessed by changes in C-peptide levels, appeared to be markedly suppressed. The fall in plasma glucose and insulin induced by rhIGF-1 would, under other circumstances, have been expected to stimulate release of glucagon and increase hepatic glucose production. However, we found that the glucagon response to hypoglycemia was absent and hepatic glucose production failed to rise above baseline with rhIGF-1. The effects of rhIGF-1 on peripheral glucose uptake are likely to have been mediated by interaction with specific type-1 IGF receptors, which are present in high density 
Table I. Cardiovascular and Cognitive Changes During the Glucose Clamp Study

\begin{tabular}{|c|c|c|c|}
\hline & $\begin{array}{l}\text { Baseline } \\
0 \mathrm{~min}\end{array}$ & $\begin{array}{l}\text { Euglycemia } \\
90-120 \mathrm{~min}\end{array}$ & $\begin{array}{l}\text { Hypoglycemia } \\
240-270 \mathrm{~min}\end{array}$ \\
\hline \multicolumn{4}{|l|}{ Heart rate } \\
\hline Insulin & $65 \pm 5$ & $69 \pm 4$ & $69 \pm 5$ \\
\hline rhIGF-1 & $67 \pm 5$ & $79 \pm 5^{\ddagger}$ & $82 \pm 6^{*}$ \\
\hline \multicolumn{4}{|c|}{ Systolic pressure } \\
\hline Insulin & $120 \pm 5$ & $122 \pm 3$ & $130 \pm 4$ \\
\hline rhIGF-1 & $124 \pm 4$ & $127 \pm 2$ & $131 \pm 3$ \\
\hline \multicolumn{4}{|c|}{ Diastolic pressure } \\
\hline Insulin & $71 \pm 3$ & $69 \pm 2$ & $63 \pm 3$ \\
\hline rhIGF-1 & $75 \pm 3$ & $70 \pm 1$ & $62 \pm 2$ \\
\hline \multicolumn{4}{|c|}{ P300 latency (ms) } \\
\hline Insulin & $300 \pm 7$ & $306 \pm 14$ & $313 \pm 13$ \\
\hline rhIGF-1 & $320 \pm 8$ & $308 \pm 6$ & $334 \pm 7$ \\
\hline \multicolumn{4}{|c|}{ P300 amplitude $(\mu \mathrm{V})$} \\
\hline Insulin & $7.0 \pm 1.0$ & $6.5 \pm 0.8$ & $4.3 \pm 0.7$ \\
\hline rhIGF-1 & $7.3 \pm 1.3$ & $6.6 \pm 0.6$ & $4.6 \pm 0.9$ \\
\hline
\end{tabular}

Values shown were measured at baseline, over the final $30 \mathrm{~min}$ of the euglycemic, and during hypoglycemic phases of the clamp study during infusion of insulin or rhIGF-1.

${ }^{*} P<0.05,{ }^{\ddagger} P<0.01$ insulin vs. rhIGF-1.

in muscle cells (20). In contrast, there are few if any IGF receptors in the liver (21). The suppression of hepatic glucose production by rhIGF-1 observed in our study may have been a result of rhIGF-1 cross-reacting with hepatic insulin receptors. Alternatively, the reduction in glucose production by the liver could also be explained by suppression of glucagon production by pancreatic alpha cells. The marked delay in glucose recovery from hypoglycemia after termination of the rhIGF-1 infusion was likely to be a consequence of failure of glucagon levels to rise significantly, persistence of high circulating levels of IGF-1 (and thus stimulation of peripheral glucose uptake), or a combination of both. It is recognized that IGF-1 has a long half-life compared with insulin because of the modulating effects of IGF-1-binding proteins (22).

The absent glucagon response to hypoglycemia observed during the free-fall study was also confirmed when we used the glucose clamp technique to produce a sustained hypoglycemic stimulus. Surprisingly, the magnitude of the inhibitory effect on glucagon release in this study was substantially greater than that observed for growth hormone. Glucagon release during hypoglycemia is thought to be mainly dependent on central

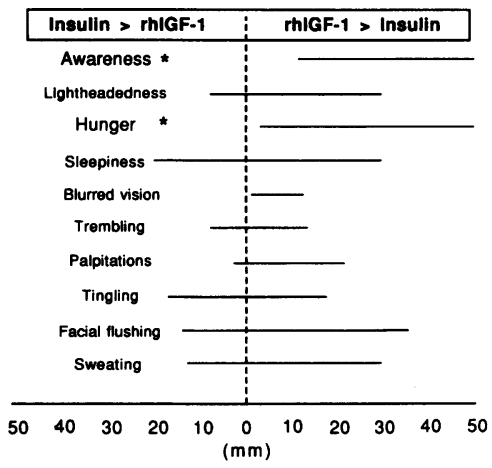

Figure 6. Differences (median [interquartile range]) in symptom scores (rhIGF-1 minus insulin) using peak changes from baseline on visual analogue scales during hypoglycemic phase of paired rhIGF-1 and insulin clamps. rather than peripheral glucopenia (23) through activation of autonomic systems (24). However, studies using the isolated buffer-perfused pancreas have reported a rise in glucagon secretion in response to hypoglycemia (25), implying regulation at the level of the alpha cell as well. In the present study the hypoglycemic stimulus was similar in both protocols, and insulin secretion, which normally inhibits glucagon release (26), was inhibited by rhIGF-1. rhIGF-1 also lowered plasma glucagon levels during the euglycemic phase of the clamp study. A similar effect during euglycemia has been reported in healthy human subjects using doses of rhIGF- 1 that were $40-50 \%$ less than used here (8). One explanation for the failure of glucagon to rise when plasma glucose was lowered might be a consequence of a direct action of rhIGF-1 on pancreatic islet cell function. Specific receptors for IGF-1 have been demonstrated in rat alpha and beta cells (27). A recent in vitro study has suggested that IGF-1 can inhibit insulin release directly, by binding to IGF-1 receptors (28); perhaps a similar effect occurs with respect to the alpha cell. It is also possible that the suppression of glucagon was due to a direct action of rhIGF-1 on IGF-1 receptors in the brain (29-31), as recently demonstrated with insulin (12), or on delta cell somatostatin secretion.

Growth hormone is a key regulator of IGF-1 production in the liver and in a variety of extrahepatic tissues (32), and release of growth hormone is thought to be influenced, through negative feedback mechanisms, by circulating levels of IGF-1 (33). As expected we found significant suppression of the growth hormone response to hypoglycemia in the free-fall study. Surprisingly, this effect was much less pronounced during the hypoglycemic phase of the glucose clamp where growth hormone responses after $60 \mathrm{~min}$ were similar to insulin and rhIGF-1 infusion. This may partly reflect the slightly longer duration of hypoglycemia and the higher insulin dose used in the clamp study (12). In comparison with our study, Guler et al. (9) found no difference in the responses of glucagon and other counterregulatory hormones to hypoglycemia induced by a bolus injection of insulin or rhIGF-1 in healthy volunteers. These discrepancies may reflect differences in methodology, as the nadir of blood glucose was lower $(<2 \mathrm{mM} /$ liter $)$ and the dose of rhIGF-1 was greater $(100 \mu \mathrm{g} / \mathrm{kg})$ in their study.

We found that infusion of rhIGF-1 caused a significantly greater increase in heart rate than insulin during both the euglycemic and hypoglycemic phases of the clamp study. This chronotropic action of rhIGF-1 was associated with increased levels of norepinephrine and greater "awareness" of hypoglycemia, findings that may reflect enhanced stimulation of sympathetic activity by rhIGF-1. This interpretation is supported by a number of in vitro studies where IGF-1 has been shown to stimulate synthesis and activation of tyrosine hydroxylase (34) and to augment the release of catecholamines from chromaffin cells in vitro $(35,36)$. Indeed, IGF-1 has even been shown to stimulate replication of pheochromocytoma cells and sympathetic neuroblasts $(37,38)$. Alternatively, the effect of rhIGF-1 on heart rate may have been a consequence of direct stimulation of IGF-1 receptors in the heart $(39,40)$.

In conclusion, use of rhIGF-1 to exploit its anabolic effects on cell growth and protein metabolism may be limited by its ability to cause hypoglycemia. Our findings show that the pattern of the acute hypoglycemic action of rhIGF-1 is similar to insulin with suppression of hepatic glucose production and stimulation of peripheral glucose uptake. Nevertheless, patients treated with rhIGF-1 may be susceptible to prolonged hypoglycemia due to inhibition of the glucagon and growth 
hormone responses and sustained suppression of a rebound increase in hepatic glucose production. Paradoxically, warning of impending hypoglycemia may be enhanced by rhIGF-1 compared with insulin, as a consequence of greater stimulation of the sympathetic nervous system. It should be emphasized that the diverse metabolic effects of intravenous infusions of IGF-1 may differ from that seen after subcutaneous administration. Free IGF-1 levels are likely to be higher after intravenous injection and this in turn could alter levels of IGF-binding proteins. Thus it remains to be determined whether chronic subcutaneous administration of IGF-1 would have comparable effects on glucose counterregulation.

\section{Acknowledgments}

The authors thank Aida Grossman and Andrea Bilous for measurement of counterregulatory hormone levels and Ralph Jacob for determination of glucose radioactivity. We also thank Neil Gesundheit of Genentech Inc. for the generous donation of recombinant human IGF1 and for the analysis of plasma IGF-1 levels.

This study was supported by grants from the National Institutes of Health (DK 20495 and RR 00125) and the Juvenile Diabetes Foundations International.

\section{References}

1. Froesch, E. R., C. Schmidt, J. Schwander, and J. Zapf. 1985. Actions of insulin-like growth factors. Annu. Rev. Physiol. 47:443-467.

2. Walker, J. L., M. Ginalska-Malinowska, T. E. Romer, J. B. Pucilowska, and L. E. Underwood. 1991. Effects of the infusion of insulin-like growth factor 1 in a child with growth hormone insensitivity syndrome. N. Engl. J. Med. 324:14831488 .

3. Ross, R. J. M., J. P. Miell, and C. R. Buchanan. 1991. Avoiding autocannabolism. Br. Med. J. 303:1147-1148.

4. Froesch, E. R., H. P. Guler, C. Schmid, K. Binz, and J. Zapf. 1990. Therapeutic potential of insulin like growth factor 1. Trends Endocrinol. Metab. 1:254260

5. Jacob, R., E. Barrett, G. Plewe, K. D. Fagin, and R. S. Sherwin. 1989. Acute effects of insulin-like growth factor-1 on glucose and amino acid metabolism in the awake fasted rat. J. Clin. Invest. 83:1717-1723.

6. Moxley, R. T., P. Arner, A. Moss, A. Skottner, M. Fox, D. James, and J. N. Livingston. 1990. Acute effects of insulin-like growth factor 1 and insulin on glucose metabolism in vivo. Am. J. Physiol. 259:E561-E567.

7. Jacob, R. J., R. S. Sherwin, L. Bowen, D. Fryburg, K. D. Fagin, W. V. Tamborlane, and G. I. Shulman. 1991. Metabolic effects of IGF-1 and insulin in spontaneously diabetic BB/w rats. Am. J. Physiol. 260:E262-E268.

8. Boulware, S. D., W. V. Tamborlane, L. S. Matthews, and R. S. Sherwin. 1992. Diverse effects of insulin-like growth factor-1 on glucose, lipid and amino acid metabolism. Am. J. Physiol. 262:E130-E133.

9. Guler, H. P., J. Zapf, and E. R. Froesch. 1987. Short-term metabolic effects of recombinant human insulin-like growth factor 1 in healthy adults. $N$. Engl. $J$. Med. 317:137-140.

10. DeFronzo, R. A., J. D. Tobin, and R. Andres. 1979. Glucose clamp technique: a method for quantifying insulin secretion and resistance. Am. J. Physiol. 237:E214-E223.

11. Diamond, M. P., T. W. Jones, S. Caprio, L. Hallarman, M. Connoly-Howard, K. Starick-Zych, W. K. Vaughn, W. V. Tamborlane, and R. S. Sherwin. 1991. Gender: a determinant of the adrenergic response to hypoglycemia. Diabetes. 40(Suppl. 1):27A.

12. Kerr, D., M. Reza, N. Smith, and B. A. Leatherdale. 1991. Importance of insulin in subjective, cognitive and hormonal response to hypoglycemia in patients with IDDM. Diabetes. 40:1057-1062.

13. Jones, T. W., G. McCarthy, W. V. Tamborlane, S. Caprio, E. Roessler, D. Kraemer, K. Starick-Zych, T. Allison, S. D. Boulware, and R. S. Sherwin. 1990. Mild hypoglycemia and impairment of brain stem and cortical evoked potentials in healthy subjects. Diabetes. 39:1550-1555.

14. Ferrannini, E., R. A. DeFronzo, and R. S. Sherwin. 1982. Transient hepatic response to glucagon in man: role of insulin and hyperglycemia. $\mathrm{Am}$. J. Physiol. 242:E73-E81.

15. Radzuik, J., K. H. Norwich, and M. Vranic. 1978. Experimental validation of measurements of glucose turnover in non-steady state. Am. J. Physiol. 234:E84-E93.
16. Lieberman, S. A., J. Bukar, S. A. Chen, A. C. Celniker, P. G. Compton, J. Cook, J. Albu, A. J. Perlman, and A. R. Hoffman. 1992. Effects of recombinant human insulin-like growth factor 1 ( rhIGF-1) on total and free IGF-1 concentrations, IGF binding proteins, and glycemic response in humans. J. Clin. Endocrinol. \& Metab. 75:30-36. In press.

17. Amiel, S. A., D. C. Simonson, W. V. Tamborlane, R. A. DeFronzo, and R. S. Sherwin. 1987. Rate of glucose fall does not affect counterregulatory hormone responses to hypoglycemia in normal and diabetic humans. 1987. Diabetes. 36:518-522.

18. Amiel, S. A., R. S. Sherwin, D. C. Simonson, and W. V. Tamborlane. 1988. Effect of intensive insulin therapy on glycemic thresholds for counterregulatory hormone release. Diabetes. 7:901-907.

19. Cody, R. P., and J. K. Smith. 1987. Repeated measures designs. In Applied Statistics and the SAS Programming Language. Elsevier/North Holland, Amsterdam. 133-177.

20. Poggi, C., Y. Le Marchand-Brustel, J. Zapf, E. R. Froesch, and P. Freychet. 1979. Effects and binding of insulin-like growth factor in the isolated soleus muscle of lean and obese mice: comparison with insulin. Endocrinology. 195:723-730.

21. Caro, J. F., J. Poulos, O. Ittoop, W. J. Pories, E. G. Flickinger, and M. K. Sinha. 1988. Insulin-like growth factor 1 binding in hepatocytes from human liver, human hepatoma, and normal, regenerating and fetal liver. J. Clin. Invest. 81:976-981.

22. Guler, H. P., J. Zapf, C. Schmid, and E. R. Froesch. 1989. Insulin-like growth factors 1 and 11 in healthy man. Estimations of half-lives and production rates. Acta Endocrinol. 121:753-758.

23. Biggers, D. W., S. R. Myers, D. Neal, R. Stinson, J. B. Jaspan, P. E. Williams, A. D. Cherrington, and R. T. Frizzel. 1989. Role of the brain in counterregulation of insulin-induced hypoglycemia in dogs. Diabetes. 38:7-16.

24. Havel, P. J., and G. J. Taborsk. 1989. The contribution of the autonomic nervous system to changes of glucagon and insulin secretion during hypoglycemic stress. Endocr. Rev. 10:332-350.

25. Weir, G., S. Knowlton, and D. Martin. 1976. Glucagon secretion from the perfused rat pancreas. J. Clin. Invest. 54:1403-1412.

26. Philippe, J. 1989. Glucagon gene transcription is negatively regulated by insulin in a hamster islet cell line. J. Clin. Invest. 84:672-677.

27. Van Schravendijk, C. F. H., A. Foriers, J. L. Van den Brande, and D. G. Pipeleers. 1987. Evidence for the presence of type 1 insulin-like growth factor receptors on rat pancreatic A and B cells. Endocrinology. 121:1784-1788.

28. Van Schravendijk, C. F. H., L. Heylen, J. L. Van den Brande, and D. G. Pipeleers. 1990. Direct effect of insulin and insulin-like growth factor-1 on the secretory activity of rat pancreatic beta cells. Diabetologia. 33:649-653.

29. Lund, P. K., B. M. Moats-Staats, M. A. Hynes, J. G. Simmons, M. Jansen, A. J. D'Ercole, and J. J. Van Wyk. 1986. Somatomedin C/insulin-like growth factor-1 and insulin-like growth factor-II mRNA's in rat fetal and adult tissues. $J$. Biol. Chem. 261:14539-14544.

30. Sara, V. R., C. Carlsson-Skwirut, C. Anderson, E. Hall, B. Sjogren, A. Holmgren, and H. Jornvall. 1986. Characterization of somatomedins from human fetal brain: identification of a variant form of insulin-like growth factor 1 . Proc. Natl. Acad. Sci. USA. 83:4904-4907.

31. Araujo, D. M., P. A. Lapchak, B. Collier, J. G. Chabot, and R. Quirion. 1989. Insulin-like growth factor-1 (somatomedin-C) receptors in the rat brain: distribution and interaction with the hippocampal cholinergic system. Brain Res. 484:130-138.

32. Sara, V. R., and K. Hall. 1990. Insulin-like growth factors and their binding proteins. Physiol. Rev. 70:591-614.

33. Abe, H., M. E. Molitch, J. J. Van Wyk, and L. E. Underwood. 1983. Human growth hormone and somatomedin $\mathrm{C}$ suppress release of growth hormone in unanesthetised rats. Endocrinology. 113:1319-1324.

34. Dahmer, M. K., P. M. Hart, and R. L. Perlman. 1991. Insulin-like growth factor-1 enhances tyrosine hydroxylase activation in bovine chromaffin cells. $J$. Neurochem. 57:1347-1353.

35. Dahmer, M. K., and R. L. Perlman. 1988. Bovine chromaffin cells have insulin-like growth factor-1 (IGF-1) receptors: IGF-1 enhances catecholamine secretion. J. Neurochem. 51:321-323.

36. Dahmer, M. K., P. M. Hart, and R. L. Perlman. 1990. Studies on the effect of insulin-like growth factor-1 on catecholamine secretion from chromaffin cells. J. Neurochem. 54:931-936.

37. Dahmer, M. K., and R. L. Perlman. 1988. Insulin and insulin-like growth factors stimulate DNA synthesis in PC12 pheochromocytoma cells. Endocrinology. 122:2109-2113.

38. DiCicco-Bloom, E., and I. B. Black. 1988. Insulin growth factors regulate the mitotic cycle in cultured rat sympathetic neuroblasts. Proc. Natl. Acad. Sci. USA. 85:4066-4070.

39. Meuli, C., and E. R. Froesch. 1977. Insulin and nonsuppressible insulinlike activity (NSILA-S) stimulate the same glucose transport system via two separate receptors in rat heart. Biochem. Biophys. Res. Commun. 75:689-695.

40. Vetter, U., C. Kupferschmid, D. Lang, and S. Pentz. 1988. Insulin like growth factors and insulin increase the contractility of neonatal rat cardiocytes in vitro. Basic Res. Cardiol. 83:647-654. 